\title{
Obituary for Wilbert Ray Shenk (January 16, 1935-July 13, 2021)
}

Wilbert Ray Shenk, 86, Mennonite missiologist and mission administrator and historian of the global Christian movement, died at his home on 13 July 2021, in Goshen, Indiana. Shenk's lifelong commitment to global service and scholarship began with the Mennonite Central Committee (MCC) in Java, Indonesia (1955-59), where he served with his wife, Juanita, in coordinating medical and educational initiatives. Later chapters of Shenk's life included roles in Overseas Ministries leadership at the Mennonite Board of Missions, now Mennonite Mission Network (1965-90), as associate professor and director of the Mission Training Center at Associated (now Anabaptist) Mennonite Biblical Seminary in Elkhart, Indiana (1990-1995), and then as a faculty member at Fuller Theological Seminary in Pasadena, California (1995-2005), continuing there until 2018 as the Paul E. Pierson Professor Emeritus of Mission History and Contemporary Culture.

Shenk was a founding member of the American Society of Missiology and served as one of the coordinators of the Pew-funded North Atlantic Missiology Project, and its successor, the Currents in World Christianity Project. On a twoyear sabbatical from mission administration in 1973-75, he began doctoral studies with professors Andrew F. Walls and Harold W. Turner at the University of Aberdeen, Scotland, completing his study with a $1978 \mathrm{PhD}$ dissertation on Henry Venn, published by Orbis Books in 1983.

Other book publications by Shenk included Earthen Vessels: American Evangelicals and Foreign Missions, 1880-1980 (1990), Changing Frontiers in Mission (1999), Enlarging the Story: Perspectives on Writing World Christian History (2002), and North American Foreign Missions, 1810-1914: Theology, Theory, and Policy (2004). In addition, Shenk wrote numerous articles and served as a consulting editor of the Dictionary of Mission Theology: Evangelical Foundations (2007) and the History of the American Society of Missiology, $1973-2013$ (2014).

In a 2006 festschrift honoring Shenk - Evangelical, Ecumenical, and Anabaptist Missiologies in Conversion, edited by James R. Krabill, Walter Sawatsky, and Charles E. Van Engen (Orbis Books) - five specific areas of 
Shenk's contribution to mission thinking and practice were highlighted. These included global mission history, evangelical/ecumenical mission theology, mission and ecclesiology, missional church perspectives, and facilitating wideranging conversations. Memories of Shenk expressed online include his "pioneering vision," "humble scholarship," "quiet kindness," and "gentle wit." While he will be greatly missed, we are grateful for his rich scholastic legacy.

James R. Krabill

Core Adjunct Faculty, Anabaptist Mennonite Biblical Seminary,

Elkhart, IN, USA 